\title{
Democracia e ditadura na teoria política de Marx e Engels

\author{
Democracy and dictatorship in the political theory \\ of Marx and Engels
}

Theófilo Codeço Machado Rodrigues*

\begin{abstract}
Resumo - O presente artigo analisa a forma como Marx e Engels, teóricos da política, inseriram-se no debate contemporâneo sobre a democracia no século XIX. Passada a Revolução Francesa de 1789, a democracia tornouse o grande tema da agenda teórica do século XIX. Mas as interpretações foram, decerto, distintas. De modo bem diferente de seus contemporâneos liberais, Marx e Engels compuseram a justificativa teórica para a ação dos trabalhadores para além da democracia burguesa. Transitando entre temas como a "verdadeira democracia", a "emancipação humana", o "comunismo" e a "ditadura do proletariado", os dois autores formularam teorias que não apenas informaram a grande polarização do século XX, mas que ainda referenciam debates sobre as possibilidades de uma alternativa ao capitalismo no século XXI. A hipótese aqui apresentada é a de que a tensão entre democracia e ditadura na obra dos dois permite interpretações díspares, o que garante sua permanência no debate atual.
\end{abstract}

Palavras-chave: teoria política; democracia; ditadura do proletariado; Karl Marx; Friedrich Engels.

\begin{abstract}
This article analyses how Marx and Engels, political theorists, entered the contemporary debate on democracy in the 19th century. After the French Revolution of 1789, democracy became the great theme of the theoretical agenda of the 19th century. But interpretations were certainly disparate. In a very different way from their liberal contemporaries, Marx and Engels composed the theoretical justification for the action of workers beyond the bourgeois democracy. Transitioning between topics such as "true democracy," "Human Emancipation," "communism," and "dictatorship of the proletariat," the two authors formulated theories that not only informed the great polarization of the 20th century, but which still are reference to debates about the possibilities of an alternative to capitalism in the $21 \mathrm{st}$ century. The hypothesis presented here is that the tension between democracy and dictatorship in the work of the two authors allows different interpretations that guarantee its permanence in the current debate.

Keywords: political theory; democracy; dictatorship of the proletariat; Karl Marx; Friedrich Engels.
\end{abstract}

\footnotetext{
* Doutor em Ciências Sociais pela Pontifícia Universidade Católica do Rio de Janeiro (PUC-Rio). Professor do Departamento de Ciência Política da Universidade Federal do Rio de Janeiro - UFRJ. Correspondência: UFRJ/ Instituto de Filosofia e Ciências Sociais (IFCS): Largo São Francisco de Paula, 1, Centro - Rio de Janeiro - RJ. CEP: 20051-070. Email:<theofilomachadorodrigues@gmail.com>.
} 


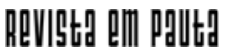

\} DEMOCRACIA E DITADURA NA TEORIA POLÍTICA DE MARX E ENGELS - RODRIGUES, T. C. M. \}

DOI: $10.12957 /$ REP.2018.36683

\section{Introdução}

Karl Marx foi um homem da ciência e $O$ Capital foi o fruto mais bem-acabado de sua pesquisa científica. "Toda a ciência seria supérflua se a forma de manifestação e essência das coisas coincidissem imediatamente", diz sua famosa frase do Livro 3 de O Capital (MARX, 2017, p. 880). Marx também foi um homem da filosofia, em particular em seus textos de juventude em diálogo com a obra de Hegel e com os jovens hegelianos; mas um filósofo da práxis, na certeira expressão gramsciana. Pois se em Hegel a coruja de Minerva só deveria alçar seu voo com o crepúsculo, em Marx a filosofia deveria ser ela própria agente da transformação. "Os filósofos só interpretaram o mundo de diferentes maneiras; do que se trata é de transforma-lo" (MARX; ENGELS, 1998, p. 103), argumenta em sua 11르 tese sobre Feuerbach. Mas, acima de tudo, Marx foi um homem da política e da teoria que a movimenta. Na política, Marx, sempre ao lado de Friedrich Engels, participou ativamente da Liga dos Comunistas, gênese do futuro partido comunista, e foi o principal dirigente da Associação Internacional dos Trabalhadores, (AIT), ou simplesmente a Primeira Internacional.

O presente artigo analisa a forma como Marx e Engels, teóricos da política, inseriram-se no debate contemporâneo sobre a democracia. Passada a Revolução Francesa de 1789, a democracia tornou-se o grande tema da agenda teórica do século XIX. Mas as interpretações foram, decerto, distintas. De modo bem diferente de seus contemporâneos liberais - Aléxis de Tocqueville e John Stuart Mill - Marx e Engels compuseram a justificativa teórica para a ação dos trabalhadores para além da democracia burguesa. Transitando por entre temas como a "verdadeira democracia", a "emancipação humana", o "comunismo" e a "ditadura do proletariado", os dois autores formularam teorias políticas que não apenas informaram a grande polarização do século XX " a chamada Guerra Fria ", como também ainda hoje referenciam debates sobre as possibilidades de uma alternativa social e política ao capitalismo no século XXI.

A hipótese aqui apresentada é a de que a tensão entre democracia e ditadura na obra de Marx e Engels permite interpretações díspares, o que garante a riqueza e a permanência do debate nos tempos atuais. A primeira seção apresenta como o jovem Marx encarou a filosofia hegeliana de sua época, definiu a "verdadeira democracia" e formulou categorias distintas, como a "emancipação humana" e a "emancipação política". A seção seguinte compreende a transição teórica de um Marx já amadurecido, presente em Manifesto comunista e nas obras históricas sobre as jornadas de 1848 e a Comuna de Paris. Daí emerge o conceito de "ditadura do proletariado". Por fim, abordaremos a forma como Engels, em texto publicado em seu último ano de vida, encarou a possibilidade da via eleitoral para a consecução da "ditadura do proletariado". 


\section{ReVIStg a d P puttg}

\} DEMOCRACIA E DITADURA NA TEORIA POLÍTICA DE MARX E ENGELS - RODRIGUES, T. C. M. \}

DOI: $10.12957 /$ REP.2018.36683

\section{O jovem Marx e a "verdadeira democracia"}

A literatura especializada é praticamente unânime ao apontar o jovem Marx, ou seja, Marx até aproximadamente seus 25 anos, como um "democrata radical". Logo após terminar seu curso de filosofia na Universidade de Berlim, em 1841, Marx passou a colaborar, no ano seguinte, com o principal jornal da burguesia democrata da região da Colônia, a Gazeta Renana. Foi ali, como editor daquele jornal, que Marx teve sua iniciação política na conturbada conjuntura prussiana. Como diz o próprio, no famoso Prefácio de 1859, "nos anos de 1842/43, como redator da Gazeta Renana vi-me pela primeira vez em apuros por ter que tomar parte na discussão sobre os chamados interesses materiais" (MARX, 1999, p. 50). No jornal, travou combate contra o parlamento renano e contra o governo prussiano, posicionando-se em defesa dos camponeses e da liberdade de imprensa. Não se tratava ainda de um comunista, mas de um democrata radical (HOBSBAWM, 2011). Os embates culminaram com o fechamento do jornal em 1843, o que o levou a Paris. Mas antes de alcançar Paris, numa parada rápida de alguns poucos meses para a lua de mel na cidade de Kreuznach, Marx enfrentou uma transição teórica de longo alcance: uma revisão profunda da obra de Hegel. Foi ali que redigiu o manuscrito de 1843, que ficou conhecido como Crítica da filosofia do direito de Hegel.

Em Crítica da filosofia do direito de Hegel, Marx (2005) enfrenta de modo inovador o tema da democracia e do Estado. Sua preocupação nesse momento é com a busca pela "verdadeira democracia", entendida como "abolição da separação entre o social e o político, o universal e o particular" (LOWY, 2012, p. 74). A "verdadeira democracia" que Marx busca é bem diferente daquela que foi efetivada pela burguesia no século anterior, em particular na Revolução Francesa. Pois, dirá Marx (2005, p. 97), essa conquista burguesa do sistema representativo apenas significa que "os membros singulares do povo são iguais no céu de seu mundo político e desiguais na existência terrena da sociedade". Não há como não notar, aqui, uma aproximação da ideia de "verdadeira democracia" marxiana com a "vontade geral" rousseauniana, i.e., a concepção de que a soberania popular deve prevalecer sobre a separação entre representante e representado, entre social e político ${ }^{1}$. Nas palavras de Celso Frederico (1995, p. 86), na democracia do jovem Marx "a extinção do Estado é substituída pela democracia direta, na qual a gestão dos assuntos públicos dispensa a presença de uma esfera autônoma, separada dos homens comuns".

Foi, contudo, apenas alguns meses após ter se concentrado em torno dos estudos sobre Hegel, em Kreuznach, que Marx efetivou um passo

\footnotetext{
Tese corroborada por Rubens Enderle (2005) e Della Volpe (1982). Aliás, em Sobre a questão judaica, Marx (2010, p. 53) cita diretamente o Contrato social de Rousseau. Por outro lado, em vez da linha Rousseau-Marx, Pogrebinschi (2007) prefere identificar a aproximação entre Marx e Spinoza, o que também concordamos, embora não seja esse o ponto a ser desenvolvido no presente artigo.
} 


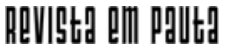

\} DEMOCRACIA E DITADURA NA TEORIA POLÍTICA DE MARX E ENGELS - RODRIGUES, T. C. M. \}

DOI: $10.12957 /$ REP.2018.36683

concreto em direção ao amadurecimento de seu pensamento. Em Paris, publicou, logo no início de 1844, dois artigos em uma revista chamada Anais FrancoAlemães: A questão judaica e Introdução à crítica da filosofia do direito de Hegel. Há aqui uma transição teórica: da ideia de "verdadeira democracia", Marx passa a entender como "emancipação humana" o lócus ideal a ser alcançado. Para Marx (2010), o fim do século XVIII e início do XIX traz para as sociedades desenvolvidas duas possibilidades de emancipação. A primeira delas é a emancipação política, entendida como a simples democracia, própria das revoluções burguesas, como as da França, Inglaterra e Estados Unidos. Em sua síntese, "a emancipação política é a redução do homem, por um lado, a membro da sociedade burguesa, a indivíduo egoísta independente" (MARX, 2010, p. 54). A emancipação humana é, no entanto, um passo para além da mera emancipação política; trata-se da emancipação plena dos homens, aquilo que antes entendeu como "verdadeira democracia" e que, posteriormente, chamará de comunismo.

Nas últimas páginas da Introdução à crítica da filosofia do direito de Hegel, Marx (2005) identifica quem será o sujeito histórico em sua teoria política: o proletariado. Mas qual seria o exato papel a ser desempenhado por esse proletariado ainda era uma incógnita naquele momento. Tratava-se mais de uma hipótese a ser testada do que uma tese comprovada pela observação empírica.

Porém, não tardou para que o teste histórico ocorresse aos olhos de Marx. Em junho de 1844, apenas quatro meses após a publicação da Introdução, explodiu na Alemanha a greve dos tecelões da Silésia. O evento, nas palavras de Michael Lowy (2010a, p. 11), representou "a primeira revolta operária na história alemã moderna, esmagada pela intervenção do exército prussiano". A greve da Silésia agitou profundamente a reflexão de Marx. Sua percepção foi a de que havia uma mudança significativa em relação às mobilizações operárias na França e na Inglaterra. Diz Marx (MARX; ENGELS, 2010b, p. 44): "a revolta silesiana começa justamente no ponto em que as revoltas dos trabalhadores da França e da Inglaterra terminam, ou seja, consciente da essência do proletariado". Diferente do que faziam os luddistas ingleses, na Alemanha "não são destruídas apenas as máquinas, essas rivais dos trabalhadores, mas também os livros contábeis, os títulos de propriedade" (MARX; ENGELS, 2010b, p. 44). Ademais, o proletariado alemão percebeu objetivamente a totalidade do adversário a ser enfrentado, qual a sua classe antagônica: "ao passo que todos os demais movimentos se voltaram apenas contra o industrial, o inimigo invisível, este movimento se voltou simultaneamente contra o banqueiro, o inimigo oculto" (MARX; ENGELS, 2010b, p. 44).

\section{A transição conceitual em Manifesto comunista}

Em novembro de 1847, Marx e Engels recebem da Liga dos Comunistas a tarefa de publicar um panfleto de divulgação das ideias do movi- 


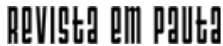

\} DEMOCRACIA E DITADURA NA TEORIA POLÍTICA DE MARX E ENGELS - RODRIGUES, T. C. M. \}

DOI: $10.12957 /$ REP.2018.36683

mento. Apesar das pressões da Liga, o que poderia sugerir certo atraso, o manuscrito não tardou a ficar pronto e em fins de fevereiro Marx entregou para a impressão em Londres sua versão final redigida em alemão. Ao fim e ao cabo, o texto que saiu dali não foi um simples panfleto de divulgação do programa dos comunistas; antes, tratava-se de um documento que sintetizava, em suas poucas páginas, uma teoria da história, uma teoria da revolução e uma teoria do partido: o Manifesto comunista.

No Manifesto, a palavra democracia aparece uma única vez. Marx e Engels (2010a, p. 57) explicam "que a primeira fase da revolução operária é a elevação do proletariado a classe dominante, a conquista da democracia". Há aqui duas possíveis interpretações. Por um lado, poderia se afirmar que para os autores a "elevação do proletariado a classe dominante" seria sinônimo de "democracia", i.e., só haveria democracia onde o proletariado fosse a classe dominante. Essa interpretação converge com a ideia anterior de "verdadeira democracia".

Outra interpretação possível seria compreender a "conquista da democracia" apenas como uma "primeira fase da revolução operária". Nesse registro "democracia" é entendida como "democracia burguesa". Essa segunda interpretação parece fazer mais sentido quando observamos a passagem que vem logo a seguir: "O proletariado usará sua supremacia política para arrancar pouco a pouco todo o capital da burguesia, para centralizar todos os instrumentos de produção nas mãos do Estado, isto é, do proletariado organizado como classe dominante" (MARX; ENGELS, 2010a, p. 57). Afinal de contas, se a "conquista da democracia" já significasse a "verdadeira democracia" ou o "comunismo", então já não seria mais necessário "arrancar pouco a pouco todo o capital da burguesia".

A "democracia" apontada no Manifesto é, portanto, a "democracia burguesa", e sua conquista é instrumental tendo em vista o objetivo posterior de chegar ao comunismo. Mas a transição conceitual iniciada no Manifesto só se completa na passagem que vem em seguida: "Isso naturalmente só poderá ser realizado, a princípio, por intervenções despóticas no direito de propriedade e nas relações de produção burguesas (MARX; ENGELS, 2010a, p. 58). A "conquista da democracia" e a consequente "supremacia política" do proletariado será acompanhada de "intervenções despóticas". Os autores ainda não utilizam a ideia de "ditadura do proletariado", mas, ao adotarem a expressão "intervenções despóticas", já estão bem próximos desse entendimento.

Com efeito, essa interpretação já aparecia em Princípios básicos do comunismo, texto pouco conhecido escrito por Engels (1982a) em novembro de 1847. Ali, um caráter instrumentalista da democracia emergia. A tarefa da revolução seria estabelecer "uma Constituição democrática do Estado, e, com ela, directa ou indirectamente, o domínio político do proletariado" (ENGELS, 1982a). Ainda em suas palavras, "a democracia seria totalmente inútil para o proletariado se ela não fosse utilizada imediatamente 


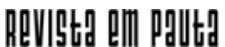

\} DEMOCRACIA E DITADURA NA TEORIA POLÍTICA DE MARX E ENGELS - RODRIGUES, T. C. M. \}

DOI: $10.12957 /$ REP.2018.36683

como meio para a obtenção de outras medidas que ataquem directamente a propriedade privada e assegurem a existência do proletariado" (ENGELS, 1982a). Ou seja, a democracia é entendida como mero meio para o proletariado tomar o poder político e acabar com a propriedade privada. A clara semelhança entre esse texto de novembro de 1847 e o de fevereiro de 1848 desmente a falsa tese de que Marx teria redigido o Manifesto sozinho e de que Engels teria apenas assinado sua coautoria. Princípios básicos do comunismo era, de fato, uma prévia do que viria a ser o Manifesto.

\section{A emergência conceitual da "ditadura do proletariado"}

Após a publicação do Manifesto, Marx passou a investir na carreira de jornalista. Sua proposta inicial foi reativar a experiência que teve em 1842-1843 com a Gazeta Renana. Assim, editou, em parceria com Joseph Weydemeyer, a Nova Gazeta Renana, um jornal diário que circulou na região da Colônia entre junho de 1848 e maio de 1849. Contingenciados pelo efervescente período histórico da Primavera dos Povos, quando movimentos revolucionários eclodiram por toda a Europa, Marx e Weydemeyer utilizaram a Nova Gazeta Renana como instrumento de divulgação daqueles eventos, em particular dos acontecidos em França e Alemanha.

Em 1849, o jornal, que já contava com cerca de 6 mil assinaturas, foi proibido pelo governo, e Marx, expulso da Alemanha, seguiu para Londres, onde morou até o fim de sua vida (ENGELS, 1976). Ao chegar em Londres, editou ainda seis números da Nova Gazeta Renana, agora em formato de revista, que foram publicados em Hamburgo, em 1850, mas sem muito sucesso. Alguns desses últimos textos de Marx sobre o movimento revolucionário francês, publicados em Hamburgo, foram reunidos em 1850 no livro As lutas de classes na França. Foi justamente em um desses textos que a expressão "intervenção despótica", adotada no Manifesto, foi substituída pelo termo "ditadura do proletariado".

Logo no primeiro capítulo de As lutas de classes na França, que trata do período que vai de fevereiro a junho de 1848, Marx observou uma mudança no conteúdo das reivindicações do proletariado ${ }^{2}$. De acordo com Marx (2012a), o processo revolucionário de fevereiro, que derrubou a monarquia de Luís Filipe, foi conformado por uma coalizão entre a burguesia e o proletariado, sob protagonismo deste último. Essa coalizão formou o governo provisório que tinha a pretensão de organizar uma república social. No entanto, essa república social defendida pelo proletariado não passou de uma ilusão.

Após a vitória de fevereiro, o proletariado passou a ser isolado e iniciou-se ali uma república burguesa. Consciente de que tinha sido o

${ }^{2}$ Esse primeiro capítulo, intitulado A derrota de junho de 1848, foi publicado originalmente em janeiro de 1850, no número 1 da versão em revista da Nova Gazeta Renana (BERTELLI, 1986). 


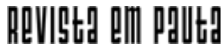

\} DEMOCRACIA E DITADURA NA TEORIA POLÍTICA DE MARX E ENGELS - RODRIGUES, T. C. M. \}

DOI: $10.12957 /$ REP.2018.36683

principal responsável pela queda da monarquia, o proletariado passou a fazer mais e mais reivindicações que, todavia, não foram atendidas pelo governo provisório. Tudo isso levou à insurreição de junho, quando milhares de trabalhadores foram massacrados pelo exército dirigido pela burguesia no poder.

O sonho de uma aliança com a burguesia em favor de uma república social havia acabado. Daí a afirmação de Marx (2012a, p. 64) de que "as exigências, exuberantes quanto à forma, mesquinhas e até ainda burguesas quanto ao conteúdo, que o proletariado parisiense quis espremer da república de fevereiro deram lugar à ousada palavra de ordem revolucionária: Derrubar a burguesia! Ditadura da classe operária!". Em outro capítulo do livro, Marx (2012a, p. 138) observou como essa transição na leitura política do proletariado passou a identificar sua ditadura com o socialismo revolucionário, com o comunismo: "Esse socialismo é a declaração de permanência da revolução, a ditadura classista do proletariado como ponto de transição necessário para abolição de todas as diferenças de classe, para a abolição da totalidade das relações de produção em que estão baseadas [...]"3.

Entre os socialistas da Alemanha, a ideia de "ditadura do proletariado" ainda estava em disputa naquele momento histórico. Em junho de 1850, o editor do Neue Deutsche Zeitung, outro jornal da esquerda alemã, condenou a utilização da expressão "ditadura do proletariado", o que levou a uma resposta de Marx em carta enviada alguns dias depois, na qual ele defendeu o seu uso (MARX, 1978). A "ditadura do proletariado" não havia entrado naqueles textos de janeiro e março de 1850 por acaso; a partir dali, passaria a fazer parte, de forma consciente, do repertório dos dois autores.

Essa virada conceitual foi confirmada pelo próprio Marx em carta enviada a Weydemeyer, seu amigo e parceiro na edição da Nova Gazeta Renana. Após o fim do jornal, em 1849, Weydemeyer transferiu-se com sua família para os Estados Unidos em 1851, país onde morou até a sua morte, em 1866. Nesse período, os dois mantiveram contato permanente. Fruto dessa parceria, o livro O 18 brumário de Luís Bonaparte surgiu a partir de uma série de textos redigidos por Marx entre dezembro de 1851 e fevereiro de 1852 para serem publicados na revista Die Revolution de Weydemeyer, em Nova York. Foi nesse contexto que, em março de 1852, Marx enviou uma carta para Weydemeyer sintetizando da forma mais clara possível a essência de sua contribuição teórica:

Nenhum crédito é devido a mim por ter descoberto a existência das classes na sociedade moderna ou a luta entre elas. Bem antes de mim, historiadores burgueses tinham descrito o desenvolvimento histórico da luta de classes, e economistas burgueses a anatomia econômica das classes. O que eu fiz de novo foi provar: (1) que a existência das classes está apenas ligada a fases históricas do desenvolvimento da produção;

${ }^{3}$ Esse capítulo, intitulado As consequências do 13 de junho de 1849, foi publicado originalmente em março de 1850, no número 3 da versão em revista da Nova Gazeta Renana (BERTELLI, 1986). 


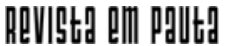

\} DEMOCRACIA E DITADURA NA TEORIA POLÍTICA DE MARX E ENGELS - RODRIGUES, T. C. M. \}

DOI: $10.12957 /$ REP.2018.36683

(2) que a luta de classes leva necessariamente à ditadura do proletariado;

(3) que essa mesma ditadura só constitui a transição para a abolição de todas as classes e para uma sociedade sem classes. (MARX, 2000, p. 371-372 " tradução nossa).

Em síntese, o que Marx demonstrou na carta para Weydemeyer foi que a sociedade sem classes, que já havia sido chamada de "verdadeira democracia" ou de "comunismo", pressupõe uma fase anterior, em que as classes ainda existem, embora a classe no poder seja o proletariado. Para essa fase anterior deu-se o nome de "ditadura do proletariado".

Embora tenha sido formulada no início da década de 1850, a ideia de "ditadura do proletariado" permaneceu como uma abstração até o início da década de 1870. Foi somente com a Comuna de Paris, em 1871, que Marx e Engels vislumbraram num evento real, concreto, sua concepção até então teórica. Durante dois meses, entre março e maio de 1871, estabeleceu-se na capital francesa um governo operário de fato, que aboliu o trabalho noturno, reduziu a jornada de trabalho e instituiu a igualdade entre os sexos, entre diversas outras conquistas. Claro, a ascensão operária não passou incólume, e em pouco tempo foi massacrada pela união das forças conservadoras de França e Alemanha. Engels (2011, p. 197), nas palavras que encerram a Introdução de 1891 para a Guerra civil na França, assegurou: "Pois bem, senhores, quereis saber como é esta ditadura? Olhai para a Comuna de Paris. Tal foi a ditadura do proletariado".

Após a derrota dos trabalhadores na Comuna de Paris, o grande palco da luta de classes na Europa seguiu da França para a Alemanha. Foi lá que, em 1875, foi constituído o mais importante partido político dos trabalhadores no continente, o Partido Social-Democrata Alemão (SPD), sob a influência teórica de Marx e Engels e a direção política de August Bebel.

No contexto do Congresso realizado na cidade de Gotha, onde o partido foi fundado, estava em debate seu programa político. Marx discordou das linhas programáticas iniciais que lá seriam apresentadas e manifestou, em manuscrito que ficou conhecido como a Crítica ao programa de Gotha, a mais clara defesa sobre o que entendia ser a tarefa do SPD: a construção da ditadura do proletariado. Diz Marx (2012b, p. 43): "entre a sociedade capitalista e a comunista, situa-se o período da transformação revolucionária de uma na outra. A ele corresponde também um período político de transição, cujo Estado não pode ser senão a ditadura revolucionária do proletariado".

Definir exatamente como seria essa ditadura do proletariado seria um erro. Essa, aliás, nunca foi a preocupação de Marx e Engels, que estavam mais interessados em estabelecer a necessidade histórica dessa fase. O que se sabe é que a ditadura em Marx nunca foi uma forma de governo institucional, mas sim o conteúdo da dominação de uma determinada classe: a ditadura da burguesia, por exemplo, poderia existir com ou sem o sufrágio universal. O que se pode derivar, a partir dos fragmentos das obras esparsas dos autores, é que a ditadura do proletariado "deveria combinar a trans-formação 


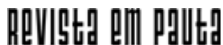

\} DEMOCRACIA E DITADURA NA TEORIA POLÍTICA DE MARX E ENGELS - RODRIGUES, T. C. M. \}

DOI: $10.12957 /$ REP.2018.36683

democrática da vida política das massas com medidas para evitar a contrarrevolução pela classe dominante derrotada" (HOBSBAWM, 2011, p. 60).

A concepção de "ditadura do proletariado" será fundamental para que os autores rompam com as críticas de que a teoria seria economicista, ou seja, de que o fator econômico é o único determinante no processo histórico. Já na descrição do método da economia política, presente na Crítica da economia política, de 1857, Marx assegurava que a realidade é síntese de múltiplas determinações. Mas foi em uma carta de Engels para Bloch de 1890 que essa concepção anti-economicista ficou mais clara. Ali, Engels explica que Marx e ele precisaram enfatizar a importância da economia num momento em que seus adversários a negavam. Algo semelhante àquilo que Lenin um dia chamou de a "teoria da curvatura da vara": quando a vara está muito inclinada para um lado, faz-se necessário forçá-la para o outro, para que, enfim, ela termine numa posição justa (ALTHUSSER, 1978, p. 136). A crítica que dessa interpretação adviria seria a seguinte: como consequência do suposto economicismo de Marx e Engels, toda ação política seria desnecessária. Algo que os autores consideram um absurdo. Responde Engels (1982b):

Assim, se alguém distorce isto afirmando que o fator econômico é o único determinante, ele transforma esta proposição em algo abstrato, sem sentido e em uma frase vazia. As condições econômicas são a infraestrutura, a base, mas vários outros vetores da superestrutura (formas políticas da luta de classes e seus resultados, a saber, constituições estabelecidas pela classe vitoriosa após a batalha, etc., formas jurídicas e mesmo os reflexos destas lutas nas cabeças dos participantes, como teorias políticas, jurídicas ou filosóficas, concepções religiosas e seus posteriores desenvolvimentos em sistemas de dogmas) também exercitam sua influência no curso das lutas históricas e, em muitos casos, preponderam na determinação de sua forma ${ }^{4}$.

A ação política é, portanto, fundamental para a história, e a ditadura do proletariado, uma necessidade. "Ou por qual razão nós lutamos pela ditadura política do proletariado se o poder político é economicamente impotente? Força (isto é, poder estatal) é também poder econômico!", conclui Engels em sua carta para Conrad Schmidt de 27 de outubro de 1890.

\section{Engels e a "democracia eleitoral" como instrumento}

Creio ter tido sucesso em demonstrar até agora que a busca de Marx e Engels por uma nova sociedade, a sociedade sem propriedade privada dos meios de produção e, consequentemente, sem classes sociais, teve diver-

\footnotetext{
${ }_{4}^{4}$ Tradução de Vinicius Valentin Raduan Miguel para o site Marxists.org. Disponível em: <https://www.marxists.org/ portugues/marx/1890/09/22.htm>.
} 


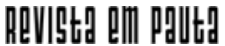

\} DEMOCRACIA E DITADURA NA TEORIA POLÍTICA DE MARX E ENGELS - RODRIGUES, T. C. M. \}

DOI: $10.12957 /$ REP.2018.36683

sos nomes: "verdadeira democracia", "emancipação humana" e "comunismo". Além disso, que a transição entre a sociedade capitalista e essa nova sociedade seria conhecida como socialismo ou ditadura do proletariado. Acredito também já ter demonstrado que essa ditadura do proletariado não é um tipo específico de regime político, com instituições próprias, mas antes um conteúdo: o governo dirigido pelos trabalhadores. Mas a forma como alcançar essa ditadura do proletariado não possui um modelo ou uma única via. Esse é o argumento dessa última seção.

Até o início da década de 1870 na Europa, em particular até a Comuna de Paris, acreditava-se ainda que o modelo da revolução socialista seria o insurrecional. Esse havia sido o modelo exportado pela França sob a referência das revoluções de 1789, 1848 e 1871. Seria, no entanto, no mínimo um equívoco acreditar que as condições políticas da Europa ocidental do fim do século XVIII seriam as mesmas do fim do século XIX. Repetir a fórmula jacobina aproximadamente 100 anos depois resultaria em desastre. Foi o que sustentou Engels (2012) em um de seus últimos textos, a Introdução para As lutas de classes na França, publicada em 1895, poucos meses antes de morrer.

"Hoje as formas de luta de 1848 são antiquadas em todos os aspectos", defendeu Engels (2012, p. 14). Mas por que antiquadas? Muitas mudanças ocorreram nos quase cinquenta anos que separam esse texto de Engels das jornadas de 1848: os exércitos cresceram; as armas desses exércitos tornaram-se cada vez mais modernas; as ferrovias também se expandiram, permitindo rápidos deslocamentos de soldados; $\mathrm{e}$ as ruas das grandes cidades foram alargadas, impedindo a organização de barricadas como as de 1848. Em suma, praticamente todas as grandes modificações favorecem aos militares no que diz respeito ao combate insurrecional.

Houve, todavia, uma mudança institucional que, se sabiamente utilizada, poderia beneficiar os trabalhadores: o sufrágio universal. Após o surgimento do SPD em 1875, já num contexto de sufrágio universal ${ }^{5}$, o crescimento do partido veio de eleição em eleição. Mesmo a Lei Antissocialista de Bismarck, que impedia que os social-democratas tivessem imprensa própria e fizessem reuniões públicas, não foi capaz de impedir a emergência do SPD. Engels (2012, p. 20) demonstra como o SPD passou de 493 mil votos em 1877 para 763 mil em 1887, 1,427 milhão em 1890 e, finalmente, 1,787 milhão em 1894. A conclusão era óbvia: eleger um governo social-democrata, pela via eleitoral, era só uma questão de tempo. A ditadura do proletariado poderia ser alcançada pela via eleitoral. De forma irônica, Engels declara: "nós, os "revolucionários", os "sublevadores", medramos muito melhor sob os meios legais do que sob os ilegais e a sublevação" (ENGELS, 2012, p. 29).

${ }_{5}^{5}$ Sufrágio universal masculino, é bom que se diga. Na Alemanha, o sufrágio universal de fato, para homens e mulheres, surgirá apenas em 1919, com a República de Weimar. 


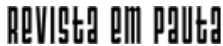

\} DEMOCRACIA E DITADURA NA TEORIA POLÍTICA DE MARX E ENGELS - RODRIGUES, T. C. M. \}

DOI: $10.12957 /$ REP.2018.36683

Note-se que há uma profunda semelhança entre a abordagem de Engels e a de Gramsci. Gramsci não cita Engels, mas sua formulação presente nos Cadernos do cárcere, em particular no Caderno 13, redigido entre 1932 e 1934, é praticamente a mesma. Gramsci percebe que o método insurrecional, ou, simplesmente, a "guerra de movimento", deixou de ser o modo da luta política após 1870. A partir de então, a arte política adotaria a ideia de "guerra de posição", ou seja, a conquista gradual de forças no seio da sociedade civil como prévia ao enfrentamento direto entre forças políticas pela conquista do aparato estatal. Diz Gramsci (2007, p. 24):

No período posterior a 1870, com a expansão colonial européia, todos esses elementos se modificam, as relações de organização internas e internacionais do estado tornam-se mais complexas e robustas; e a fórmula da "revolução permanente", própria de 1848, é elaborada e superada na ciência política com a fórmula de "hegemonia civil". Ocorre na arte política o que ocorre na arte militar: a guerra de movimento torna-se cada vez mais guerra de posição.

Foi, no entanto, uma outra interpretação desse texto de Engels que se sagrou vitoriosa: aquela que reduziu toda a luta política à dinâmica eleitoral parlamentar. Os quadros do SPD que nesse momento atuavam com desenvoltura no parlamento adotaram o texto de Engels como justificativa teórica para a prioridade programática da via eleitoral. Retiraram as passagens que não Ihes interessavam e divulgaram na imprensa social-democrata uma versão moderada e conciliadora de Engels, o que lhe causou profundo desconforto. Em carta escrita em Londres e endereçada ao genro de Marx, Paul Lafargue, em 3 de abril, Engels (apud MORAES, 2001, p. 37) denunciava esse fato:

Liebknecht acaba de me pregar uma bela peça ('joli tour'). Ele extraiu de minha introdução aos artigos de Marx sobre a França de 1848-1850 tudo que pode lhe servir para sustentar a tática a todo custo 'pacífica e antiviolenta' que lhe apraz defender, há algum tempo [...]. Mas essa tática, eu só a preconizo para a Alemanha de hoje e ainda assim com muita reserva. Para a França, a Bélgica, a Itália, a Áustria, essa tática não poderia ser inteiramente seguida e, para a Alemanha, ela poderá amanhã se tornar inaplicável.

Engels sabia que a questão não era tão simples. Em seu texto de 1895 deixava claro que na legalidade democrática burguesa o SPD poderia até avançar, mas, acaso alcançasse a maioria eleitoral necessária para go-vernar, ou seja, para implementar a ditadura do proletariado, nesse exato momento seria a própria classe burguesa quem passaria para a ilegalidade. Nas palavras de Engels (2012, p. 29), "acabará não lhes restando outra saída senão violar pessoalmente essa legalidade que lhes é tão fatal".

Engels sabia que em algum momento a conquista da ditadura do proletariado exigiria a violência revolucionária e não apenas o pacifismo 


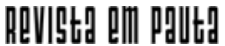

\} DEMOCRACIA E DITADURA NA TEORIA POLÍTICA DE MARX E ENGELS - RODRIGUES, T. C. M. \}

DOI: $10.12957 /$ REP.2018.36683

parlamentar. Mas isso os dirigentes da II Internacional preferiam esconder. Dentre as consequências dessas interpretações diversas do texto de Engels estão a polêmica entre Rosa Luxemburgo e Bernstein em 1900, a crise da votação dos créditos de guerra em 1914, o fim da II Internacional em 1916, a polêmica entre Kautsky e Lenin em 1918, o assassinato de Rosa Luxemburgo e Karl Liebknecht ${ }^{6}$ em 1919 e o racha entre social-democratas e comunistas ao longo do século XX.

\section{Considerações finais}

Em sua conhecida polêmica contra Kautsky, em 1918, Lenin (1971) criticou o fato de o alemão tratar a democracia como algo abstrato, acima das classes sociais. Existira para Kautsky uma "democracia pura", independentemente da existência material das classes sociais. "Pode-se, pois, dizer que a democracia é possível sem o socialismo, e que pode mesmo ser realizada antes dele", argumentava Kautsky (1979). A discordância de Lenin (1971, p. 35) foi ríspida: A "democracia pura" é somente uma frase enganosa de liberal que procura lograr os operários. A história conhece a democracia burguesa que substituiu o feudalismo e a democracia proletária que substituiu a democracia burguesa". Os dois, profundos conhecedores de Marx, partiram de Marx para conclusões completamente diversas, e, por causa dessas interpretações distintas, um mar se abriu entre social-democratas e comunistas ao longo do século XX. Diga-se de passagem, um terceiro vértice nessa disputa ainda surgia, entre Kautsky e Lenin, com os últimos trabalhos de Rosa Luxemburgo (2011, p. 210), para quem "a tarefa histórica do proletariado, quando toma o poder, consiste em instaurar a democracia socialista, no lugar da democracia burguesa, e não em suprimir toda democracia". O debate estava em aberto.

O presente artigo demonstrou que uma leitura marxiana, ou seja, da obra direta de Marx, permite afirmar que as duas interpretações possuem erros e acertos. Mas como isso é possível? Hoje sabemos que nem Kautsky, nem Lenin conheceram toda a obra de Marx e Engels, particularmente seus textos de juventude. Foi o trabalho de David Riazanov no Instituto Marx e Engels e o projeto da Marx Engels Gesamtausgabe (Mega) que trouxeram à luz muitos desses textos até então originais ${ }^{7}$.

A Ideologia alemã, que no Prefácio de 1859 Marx declarou ter deixado para "a crítica roedora dos ratos", foi publicada por Riazanov apenas

\footnotetext{
${ }^{6}$ Karl Liebknecht é filho de Wilhelm Liebknecht, o fundador do SPD que Engels acusou de desvirtuar seu texto. Karl, no entanto, não compactuava com o revisionismo do pai. Assim, atuou na ala esquerda do SPD, junto a Rosa Luxemburgo, com quem fundou o Partido Comunista Alemão. Os dois foram assassinados em janeiro de 1919 por milícias apoiadas pelo SPD. Sobre isso, ver: Benjamin (1999), Varela (2017) e Lowy (2010b).

7 Após a Revolução Russa de 1917, Riazanov foi o responsável por organizar as obras completas de Marx e Engels. Sobre esse processo, ver: Cerqueira (2010).
} 


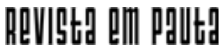

\} DEMOCRACIA E DITADURA NA TEORIA POLÍTICA DE MARX E ENGELS - RODRIGUES, T. C. M. \}

DOI: $10.12957 /$ REP.2018.36683

em 1926, dois anos após a morte de Lenin. Já a Crítica da filosofia do direito de Hegel foi publicada somente em 1927. Compreende-se, assim, a razão de Lenin não considerar possível uma "democracia pura": não conhecia ainda a defesa da "verdadeira democracia" feita por Marx em 1843.

Por outro lado, se a ideia de uma 'democracia pura", como Kautsky (1979) apontou, era possível, o líder da II Internacional equivocava-se, do ponto de vista marxiano, em desconectar essa "democracia pura" do mundo material das classes sociais. Pois, para Marx, sempre foi claro que a "verdadeira democracia" era bem diferente da democracia burguesia, i.e., da democracia realmente existente naquele momento histórico: a "verdadeira democracia" era um lócus a ser alcançado, em que a divisão entre representantes e representados não mais existisse: em outras palavras, o comunismo.

Desse dissenso, ou dessa tensão entre democracia e ditadura no âmbito da teoria política marxista, muitas correntes surgiram. A principal e mais conhecida polêmica deteve-se entre comunistas e social-democratas, bolcheviques e mencheviques. Mas inúmeras outras interpretações desenvolveram-se ao longo do século XX, como o "austromarxismo" de Otto Bauer e Max Adler, o "comunismo de conselhos" de Anton Pannekoek, Herman Gorter, Karl Korsch, Otto Ruhle e Paul Mattick, e o "eurocomunismo" de Enrico Berlinguer, Santiago Carrillo e George Marchais. No período mais recente, teóricas do pós-marxismo como Nancy Fraser e Chantal Mouffe têm buscado atualizar o debate em torno de temas como "democracia radical" e "redistribuição e reconhecimento", prova de que o debate acerca da relação entre democracia e socialismo continua mais vivo do que nunca. 


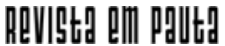

\} DEMOCRACIA E DITADURA NA TEORIA POLÍTICA DE MARX E ENGELS - RODRIGUES, T. C. M. \}

DOI: $10.12957 /$ REP.2018.36683

\section{Referências}

ALTHUSSER, L. Posições. Rio de Janeiro: Edições Graal, 1978.

BENJAMIN, C. Apresentação. In: LUXEMBURGO, R. Reforma ou revolução? São Paulo: Expressão popular, 1999.

BERTELLI, A. R. Uma introdução polêmica. In: MARX, K. As lutas de classe na França. São Paulo: Global, 1986.

CERQUEIRA, H. E. da G. David Riazanov e a edição das obras de Marx e Engels. EconomiA, Brasília (DF), v.11, n.1, jan./abr. 2010.

DELLA VOLPE, G. Rousseau e Marx - A liberdade igualitária. Lisboa: Edições 70, 1982.

ENDERLE, R. Apresentação. In: MARX, K. Crítica da filosofia do direito de Hegel. São Paulo: Boitempo, 2005.

ENGELS, F. Marx e a "Nova Gazeta Renana" (1848-1849). In: MARX, K.; ENGELS, F. Textos. Vol. 2. São Paulo: Ed. Alfa-Ômega, 1976.

. Princípios básicos do comunismo. In: MARX, K.; ENGELS, F. Obras escolhidas. Lisboa: Edições Progresso, 1982a.

. Carta a Bloch. In: MARX, K.; ENGELS, F. Obras escolhidas. Vol. 3. São Paulo: Alfa Ômega, 1982b.

Boitempo, 2011.

Introdução. In: MARX, K. A guerra civil na França. São Paulo:

. Prefácio. In: MARX, K. As lutas de classes na França. São Paulo: Boitempo, 2012.

FREDERICO, C. O jovem Marx: as origens da ontologia do ser social. São Paulo: Cortez, 1995.

GRAMSCI, A. Cadernos do cárcere. Vol. 3. Rio de Janeiro: Civilização brasileira, 2007.

HOBSBAWM, E. Como mudar o mundo: Marx e o marxismo. São Paulo: Companhia das letras, 2011.

KAUTSKY, K. A ditadura do proletariado. São Paulo: Liv. Ed. Ciências Humanas, 1979.

LENIN, V. I. A revolução proletária e o renegado Kautsky. Póvoa de Varzim: Ed. Nosso Tempo, 1971.

LOWY, M. Prefácio. In: MARX, Karl; ENGELS, Friedrich. Lutas de classe na Alemanha. São Paulo: Boitempo, 2010 .

. A centelha se acende na ação: a filosofia da práxis no pensamento de Rosa Luxemburgo. Margem Esquerda, N. 15. São Paulo: Boitempo, 2010 b. 


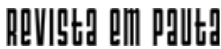

\} DEMOCRACIA E DITADURA NA TEORIA POLÍTICA DE MARX E ENGELS - RODRIGUES, T. C. M. \}

DOI: $10.12957 /$ REP.2018.36683

LOWY, M. A teoria da revolução no jovem Marx. São Paulo: Boitempo, 2012.

LUXEMBURGO, Rosa. Textos escolhidos. Volume 2. São Paulo: Ed. Unesp, 2011.

MARX, Karl. To the editor of the Neue Deutsche Zeitung. In: MARX, K.; ENGELS, F. Marx-Engels Collected Works. Vol. 10. London: Lawrence \& Wishart, 1978. 1999.

. Prefácio. In: MARX, K. Os pensadores. São Paulo: Ed. Nova Cultural, . Marx to Weydemeyer, 5 march 1852. In: MCLELLAN, D. (Org.). Karl Marx selected writings. New York: Oxford University Press, 2000.

. Crítica da filosofia do direito de Hegel. São Paulo: Boitempo, 2005. . Sobre a questão judaica. São Paulo: Boitempo, 2010.

. A guerra civil na França. São Paulo: Boitempo, 2011.

. As lutas de classe na França. São Paulo: Boitempo, 2012a.

. Crítica do Programa de Gotha. São Paulo: Boitempo, 2012b.

. O Capital. Livro 3. São Paulo: Boitempo, 2017.

MARX, K.; ENGELS, F. A ideologia alemã. São Paulo: Martins Fontes, 1998. . Manifesto comunista. São Paulo: Boitempo, 2010 a.

. Lutas de classe na Alemanha. São Paulo: Boitempo, 2010 b.

MORAES, J. Q. de. Contra a canonização da democracia. Crítica Marxista, São Paulo, n. 12, 2001.

POGREBINSCHI, T. O enigma da democracia em Marx. Rev. bras. Ci. Soc., São Paulo, v. 22, n. 63, fev. 2007.

VARELA, R. A guerra das guerras, a revolução das revoluções (1917). Rev. Direito e Práxis., Rio de Janeiro, v. 8, n. 3, 2017.

DOI: $10.12957 /$ rep.2018.36683

Recebido em 23 de abril de 2018.

Aceito para publicação em 31 de maio de 2018.

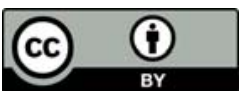

A Revista Em Pauta: Teoria Social e Realidade Contemporânea está licenciada com uma Licença Creative Commons Atribuição 4.0 Internacional. 